\title{
Distribution of axial length and related factors in an adult population of Mexico City
}

\section{Distribución de la longitud axial y factores relacionados en una población adulta de la Ciudad de México}

\author{
$M^{a}$ Soledad Barlatey*, Wilson Koga-Nakamura, Mª Victoria Moreno-Londoño, Mariana Takane-Imay and \\ $M^{a}$ Cristina González-González
}

Servicio de Ecografía Ocular, Instituto de Oftalmología Fundación Conde de Valenciana, Mexico City, Mexico

\begin{abstract}
Background: The aim of the study was to analyze the axial length (AL), anterior chamber depth (ACD), lens thickness (LT), and vitreous chamber depth (VCD) in an adult population from Mexico City and the surrounding area with a diagnosis of cataract. Methods: This was a retrospective and descriptive study. We reviewed the medical files of subjects undergoing an ultrasound examination as part of the pre-surgical routine evaluation during a period of 6 months (June 1, 2013-December 31, 2013). Biometric parameters were available for 865 eyes after applying the exclusion criteria. All measurements were made using the Ocuscan ${ }^{\circledR}$ RxP ultrasonic biometer (Alcon Laboratories, Fort Worth, Texas, USA). Results: The study included 430 eyes. Mean AL was $23.44 \pm 1.71 \mathrm{~mm}$ (median: 23.15; range: 20.48-35.05 mm; 23.27-23.60, 95\% confidence interval [Cl]). Mean ACD was $3.12 \pm 0.46 \mathrm{~mm}$ (median: $3.13 \mathrm{~mm}$; range: 1.77-4.54 mm; 3.07-3.16, 95\% Cl). Mean LT was $4.47 \pm 0.57 \mathrm{~mm}$ (median: $4.50 \mathrm{~mm}$; range: 3.18-5.78; 4.41-4.52, 95\% Cl). Mean VCD was $15.81 \pm 1.63 \mathrm{~mm}$ (median: $15.58 \mathrm{~mm}$; range: $12.98-$ 26.78; 15.66-15.97, 95\% Cl). Mean age of the patients was $70.03 \pm 10.50$ years (median 70 years, range 40 96 years). Conclusion: In a Mexican adult population from Mexico City, particularly in women, a lower AL and ACD were observed. Compared to other studies, the AL was found within an average range. Age and sex were significantly associated with the other parameters evaluated in this study.
\end{abstract}

Key words: Axial length. Anterior chamber depth. Lens thickness. Vitreous chamber depth.

\section{Resumen}

Objetivo: Analizar la longitud axial, profundidad de cámara anterior, grosor del cristalino y profundidad de cámara vítrea en una población adulta de la ciudad de México y alrededores con diagnóstico de catarata. Métodos: Estudio retrospectivo y descriptivo. Se revisaron los expedientes de un período de 6 meses (de 1 de junio de 2013 a 31 de diciembre de 2013) de sujetos sometidos a un examen ecográfico como parte de su rutina prequirúrgica. Los parámetros biométricos estaban disponibles para 865 ojos después de aplicar los criterios de exclusión. Todas las mediciones fueron realizadas utilizando

Correspondence:

${ }^{*} \mathrm{M}$ ' Soledad Barlatey,

Chimalpopoca, 14

Col. Obrera, Del. Cuauhtemoc

Date of reception: 29-01-2019

Date of acceptance: 13-06-2019

E-mail: sol_barlatey@ hotmail.com

DOI: 10.24875/RMOE.M19000082
Available online: 01-09-2019 Rev Mex Oftalmol (Eng). 2019;93(5):12-16 www.rmo.com.mx 2604-1731/O 2019 Sociedad Mexicana de Oftalmología. Published by Permanyer México SA de CV. This is an Open Access article under the CC BY-NC-ND license (http://creativecommons.org/licenses/by-nc-nd/4.0/). 
el biómetro ultrasónico Ocuscan RxP (Alcon Laboratories, Fort Worth, Texas, EE.UU). Resultados: El estudio incluyó 430 ojos. La longitud axial media fue de $23.44 \pm 1.71 \mathrm{~mm}$ (mediana: 23.15; rango: 20.48-35.05 mm; IC 95\%: 23.27-23.60). La profundidad de cámara anterior media fue de $3.12 \pm 0.46 \mathrm{~mm}$ (mediana: $3.13 \mathrm{~mm}$; rango: 1.77-4.54 mm; IC 95\%: 3.07-3.16). EI grosor cristaliniano medio fue de $4.47 \pm 0.57 \mathrm{~mm}$ (mediana: $4.50 \mathrm{~mm}$; rango: 3.18-5.78; IC 95\%: 4.41-4.52). La profundidad de cámara vítrea media fue de $15.81 \pm 1.63 \mathrm{~mm}$ (mediana: $15.58 \mathrm{~mm}$; rango: 12.98-26.78; IC 95\%: 15.66-15.97). La edad media de los pacientes fue de $70.03 \pm 10.50$ años (mediana 70 años, rango 40-96 años). Conclusiones: En la población adulta mexicana de la Ciudad de México, particularmente en las mujeres, se encontró una menor longitud axial y profundidad de cámara anterior. Comparado con otros estudios, la longitud axial se encontró dentro de un rango promedio. La edad y el sexo estuvieron significativamente asociados con los demás parámetros evaluados en este estudio.

Palabras clave: Longitud axial. Profundidad de cámara anterior. Grosor cristaliniano. Profundidad de cámara vítrea.

\section{Introduction}

At the end of the $19^{\text {th }}$ century, the British physicist and mathematician William Thompson Kelvin (18241907) said that "If you cannot measure it, you cannot improve it." Such is the case for axial length (AL) measurement, an important and necessary ophthalmic parameter for the calculation of intraocular lens power prior to cataract and refractive surgery ${ }^{1}$, and useful for the early diagnosis of ocular conditions such as microphthalmos and/or nanophthalmos, staphyloma ${ }^{2}$ and for the risk of retinal detachment ${ }^{3}$.

Several studies have shown the correlation between ocular biometrics, especially AL, with refractive errors. Hosny et al. ${ }^{4}$ found that corneal diameter, spherical equivalent, and anterior chamber depth $(A C D)$ affect $A L$ parameters. In a study conducted at the University of Shanghai by Wang et al. ${ }^{5}$ that measured the AL of 255 eyes, an AL of $23.63 \mathrm{~mm} \mathrm{(} \pm 0.92)$ was observed in hyperopic subjects, $24.62 \mathrm{~mm}( \pm 0.38)$ in emmetropic subjects, and $26.68 \mathrm{~mm}( \pm 0.75)$ in myopic subjects. Since these parameters may be influenced by race, ethnicity, and genetics, their differences between different populations can probably explain refractive error variations.

Some Asian countries such as Taiwan, Myanmar, Singapore, and China ${ }^{6-9}$ have published population reports related to the distribution of ocular biometrics.

A review of several studies using different measurement techniques shows that $\mathrm{AL}$ measurement of the adult normal eye is of approximately $23.60 \mathrm{~mm}^{10,11}$, taken from the corneal apex to the internal limiting membrane (ILM). However, most individuals are in the range of $22.00-24.50 \mathrm{~mm}$.

Hoffer showed that the average ACD in phakic eyes is of $3.24 \mathrm{~mm}( \pm 0.44 \mathrm{~mm})^{11}$ and concluded, in a study of 7500 eyes, that the thickness of a cataractous lens (lens thickness [LT]) is of $4.63 \mathrm{~mm}^{10}$.

\section{Objective}

Our study shows the distribution of $A L$ and its components, including ACD, LT, and vitreous chamber depth (VCD), in a Mexican population aged 40-99 years with a diagnosis of cataract.

\section{Methods}

All measurements were made with the Ocuscan RxP ultrasonic biometer (Alcon Laboratories, Fort Worth, Texas, USA) during the period from June to December 2013. The ultrasonic biometer measures from the cornea to the ILM. The measurements were recorded in automatic mode, with the immersion technique, to avoid corneal flattening and obtaining results comparable to optical biometrics.

$A L$ is defined as the distance from the anterior aspect of the cornea to the ILM. ACD is defined as the distance from the anterior aspect of the cornea (corneal epithelium) to the anterior aspect of the lens, and LT is defined by its anterior and posterior aspects, and VCD is measured from the back of the lens to the ILM.

Each ocular biometrics index was defined by its mean and a $95 \%$ confidence interval $(\mathrm{Cl})$ by age and gender, and the normal range was calculated as the mean of \pm 2 standard deviations. The $5^{\text {th }}, 10^{\text {th }}, 25^{\text {th }}, 50^{\text {th }}, 75^{\text {th }}, 90^{\text {th }}$, and $95^{\text {th }}$ percentiles were estimated to show the distribution of these variables in more detail.

To assess distributions different from normal, they were plotted in histograms. Pearson's correlation coefficients were determined by examining the correlation between both eyes in terms of AL and its components.

In this report, only phakic eyes were included for analysis, and subjects with a history of eye surgery were excluded from the study. The correlation between the right and left eyes was high for the AL $(r=0.997)$, ACD $(r=0.980)$, LT $(r=1.015)$, and VCD $(r=0.999)$ indices; therefore, we present here only the results of the right eyes. 
Table 1. Distribution of $A L, A C D, L T$, and VCD with means and $95 \% \mathrm{Cl}$ by age and gender

\begin{tabular}{|c|c|c|c|c|c|}
\hline Age (years) & $\mathbf{N}$ & AL (mm) mean ( $95 \% \mathrm{CI})$ & ACD $(\mathrm{mm})$ mean $(95 \% \mathrm{CI})$ & LT (mm) mean (95\% Cl) & VCD $(\mathrm{mm})$ mean $(95 \% \mathrm{CI})$ \\
\hline $\begin{array}{l}\text { Male } \\
40-49 \\
50-59 \\
60-69 \\
70-79 \\
80+\end{array}$ & $\begin{array}{c}5 \\
19 \\
34 \\
40 \\
31\end{array}$ & $\begin{array}{l}23.03(22.66-23.41) \\
23.99(23.66-24.32) \\
23.55(23.02-24.08) \\
23.89(23.48-24.30) \\
23.67(23.39-23.95)\end{array}$ & $\begin{array}{l}3.55(3.02-3.42) \\
3.47(3.27-3.66) \\
3.22(3.02-3.42) \\
3.25(3.10-3.40) \\
3.17(3.01-3.33)\end{array}$ & $\begin{array}{l}4.11(3.62-4.60) \\
4.15(3.93-4.37) \\
4.49(4.27-4.71) \\
4.39(4.20-4.58) \\
4.60(4.40-4.80)\end{array}$ & $\begin{array}{l}15.39(15.15-15.62) \\
16.36(16.04-16.68) \\
15.83(15.33-16.33) \\
16.23(15.84-16.62) \\
15.89(15.61-16.17)\end{array}$ \\
\hline $\begin{array}{l}\text { Female } \\
40-49 \\
50-59 \\
60-69 \\
70-79 \\
80+\end{array}$ & $\begin{array}{c}9 \\
43 \\
85 \\
113 \\
51\end{array}$ & $\begin{array}{l}24.36 \text { (22.45-26.28) } \\
23.56(22.81-24.81) \\
23.41(22.91-23.90) \\
23.26(22.96-23.57) \\
22.87(22.71-23.04)\end{array}$ & $\begin{array}{l}3.50(3.04-3.97) \\
3.16(3.02-3.31) \\
3.10(3.01-3.19) \\
3.02(2.93-3.10) \\
2.90(2.79-3.00)\end{array}$ & $\begin{array}{l}4.02(3.53-4.51) \\
4.21(4.04-4.38) \\
4.47(4.35-4.59) \\
4.55(4.55-4.66) \\
4.71(4.56-4.87)\end{array}$ & $\begin{array}{l}16.83(15.02-18.64) \\
16.16(15.45-16.86) \\
15.83(15.36-16.30) \\
15.59(15.31-15.88) \\
15.25(15.06-15.45)\end{array}$ \\
\hline Total & 430 & $23.44(23.27-23.60)$ & $3.12(3.07-3.16)$ & $4.47(4.41-4.52)$ & 15.81 (15.66-15.97) \\
\hline
\end{tabular}

AL: axial length; ACD: anterior chamber depth; LT: lens thickness; VCD: vitreous chamber depth; CI: confidence intervals.

Statistical analysis was performed using a commercially available statistical software package, Statistical Package for the Social Sciences version 19, Chicago, Illinois, USA.

The study was reviewed and approved by the Ethics Committee of the Conde de Valenciana Institute of Ophthalmology in Mexico City.

\section{Results}

Of a total of 565 patients, AL measurements and its associated parameters were available for 865 eyes (440 right and 405 left). Of the 440 right eyes studied, 10 were excluded due to a history of ocular surgery. Finally, a total of 430 eyes were included in the study. Mean patient age was $70.03 \pm 10.50$ years (median 70 years, range $40-96$ years).

The results in terms of mean and $95 \% \mathrm{Cl}$ of the mean of AL, ACD, LT, and VCD studied by gender and age, the mean \pm 2 SD of these variables by age and gender, and the $5^{\text {th }}, 10^{\text {th }}, 25^{\text {th }}, 50^{\text {th }}, 75^{\text {th }}, 90^{\text {th }}$, and $95^{\text {th }}$ percentiles of these variables are summarized in Tables 1, 2, and 3 , respectively. Figure 1 shows the distribution histogram of AL, ACD, LT, and VCD. Table 3 summarizes the asymmetry and kurtosis of the variables.

Mean AL was $23.44 \pm 1.71 \mathrm{~mm}$ (median: 23.15 ; range: 20.48-35.05 mm; 95\% Cl 23.27-23.60).

Mean ACD was $3.12 \pm 0.46 \mathrm{~mm}$ (median: $3.13 \mathrm{~mm}$; range: $1.77-4.54 \mathrm{~mm}$; $95 \% \mathrm{Cl}$ : 3.07-3.16).

Mean LT was $4.47 \pm 0.57 \mathrm{~mm}$ (median: $4.50 \mathrm{~mm}$; range: $3.18-5.78 ; 95 \% \mathrm{Cl}$ : 4.41-4.52). Mean VCD was $15.81 \pm 1.63 \mathrm{~mm}$ (median: $15.58 \mathrm{~mm}$; range: 12.9826.78; 95\% Cl: 15.66-15.97).

Variations by gender were observed in all the parameters evaluated. Women had a lower AL, mainly explained
Table 2. Range ( \pm 2 standard deviation) of $A L, A C D, L T$, and VCD by sex and age

\begin{tabular}{|c|c|c|c|c|}
\hline $\begin{array}{l}\text { Age } \\
\text { (years) }\end{array}$ & AL $(\mathrm{mm})$ & ACD $(\mathrm{mm})$ & $\mathrm{LT}(\mathrm{mm})$ & VCD $(\mathrm{mm})$ \\
\hline $\begin{array}{c}\text { Male } \\
40-49\end{array}$ & $22.73-23.38$ & $2.89-3.88$ & $3.66-4.61$ & $15.23-15.67$ \\
$50-59$ & $22.69-25.23$ & $2.85-4.07$ & $3.41-4.97$ & $15.49-18.00$ \\
\hline $60-69$ & $21.17-29.56$ & $2.32-4.54$ & $3.46-5.66$ & $13.42-21.19$ \\
\hline $70-79$ & $22.31-28.15$ & $1.77-4.11$ & $3.23-5.38$ & $14.65-20.72$ \\
\hline $80+$ & $21.38-25.42$ & $2.40-3.97$ & $3.40-5.51$ & $13.77-17.53$ \\
\hline & & & & \\
\hline Female & & & & \\
\hline $40-49$ & $21.04-28.45$ & $2.46-4.34$ & $3.20-5.10$ & $13.57-20.51$ \\
$50-59$ & $20.81-33.52$ & $2.12-4.26$ & $3.18-5.43$ & $13.51-25.35$ \\
$60-69$ & $20.48-35.05$ & $2.24-4.12$ & $3.28-5.78$ & $12.98-26.78$ \\
$70-79$ & $21.11-31.51$ & $2.04-4.07$ & $3.33-5.74$ & $13.22-22-29$ \\
$80+$ & $21.84-24.75$ & $2.40-3.97$ & $3.54-5.73$ & $13.57-17.48$ \\
\hline
\end{tabular}

$A L:$ axial length; ACD: anterior chamber depth; LT: lens thickness; VCD: vitreous chamber depth.

by a lower ACD and a lower VCD. However, they showed a somewhat higher LT.

Subjects from 40 to 49 years of age, compared to subjects over 80 years of age, showed a higher $A L$ (mean difference, $0.72 \mathrm{~mm}$ ), a higher ACD (mean difference, $0.52 \mathrm{~mm}$ ), and a higher VCD (mean difference, $0.82 \mathrm{~mm}$ ). However, subjects over 80 years had a higher LT (mean difference, $0.62 \mathrm{~mm}$ ). Among people aged 50-59, on average, a lower AL (mean difference, $0.20 \mathrm{~mm}$ ) was observed compared to younger people (40-49). Older subjects showed a lower ACD $(0.26 \mathrm{~mm})$ and a lower VCD $(0.09 \mathrm{~mm})$, but a higher LT $(0.14 \mathrm{~mm})$.

When analyzed by decades, the parameters of $A L, A C D$, and VCD decreased at the expense of an increase in LT.

\section{Discussion}

Our study provides information on the ocular biometric components in Mexican adults over 40 years of age who live in and around Mexico City. 


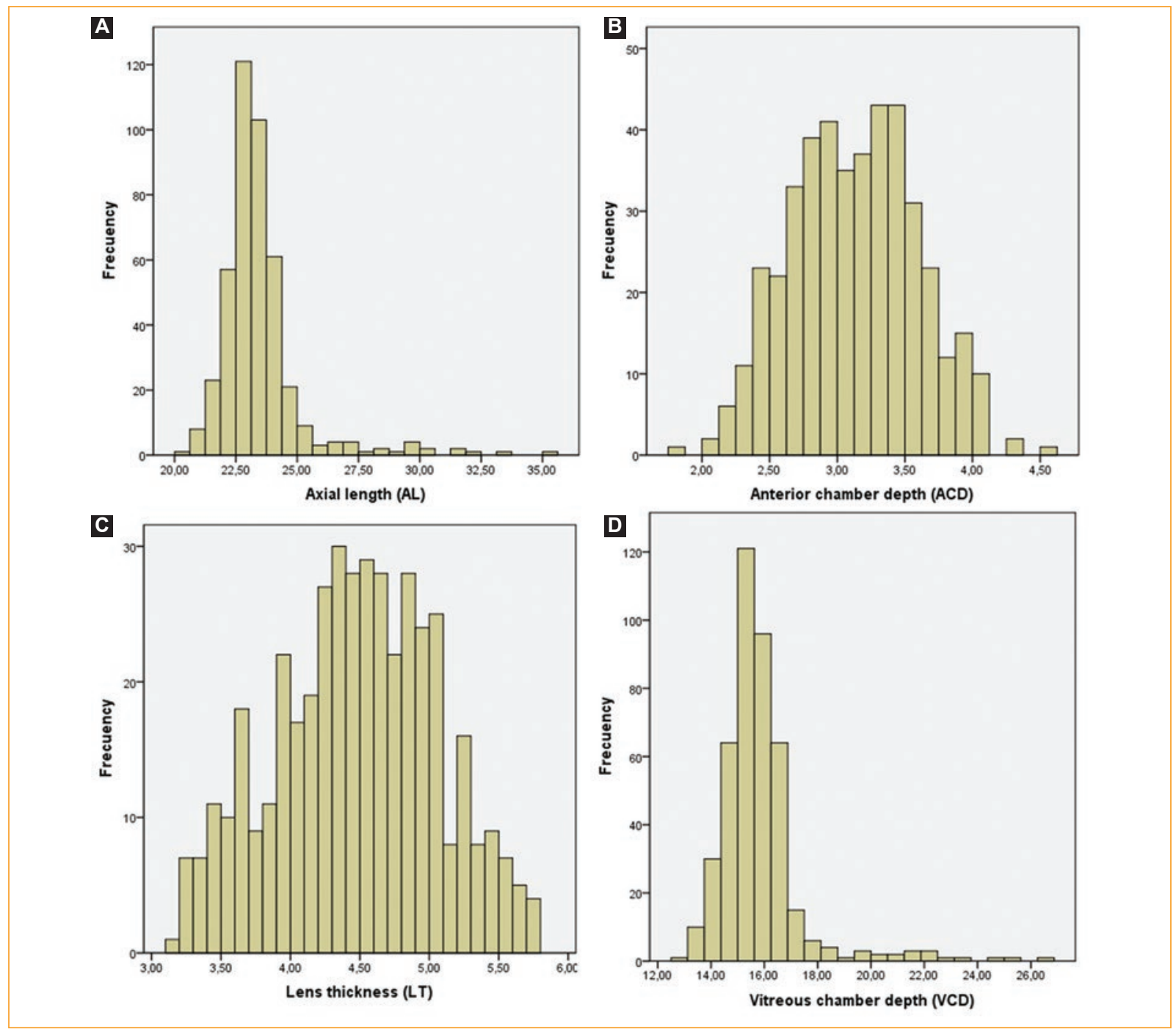

Figure 1. Axial length distribution (A), anterior chamber depth (B), lens thickness (C), vitreous chamber depth (D).

Table 3. Percentiles, asymmetry, kurtosis, and interquartile range of $A L, A C D$, $L T$, and VCD

\begin{tabular}{|l|c|c|c|c|c|c|c|c|c|c|}
\hline & \multicolumn{9}{|c|}{ Percentiles } & \multicolumn{4}{c|}{ Normal distribution rates } \\
\hline & $5 \%$ & $10 \%$ & $25 \%$ & $50 \%$ & $75 \%$ & $90 \%$ & $95 \%$ & Asymmetry & Kurtosis & Interquartile range \\
\hline AL & 21.68 & 21.99 & 22.59 & 23.15 & 23.85 & 24.63 & 26.53 & 2.99 & 12.81 & 1.26 \\
\hline ACD & 2.38 & 2.47 & 2.79 & 3.13 & 3.44 & 3.70 & 3.93 & 0.06 & -0.40 & 0.65 \\
\hline Lens thickness & 3.49 & 3.64 & 4.08 & 4.50 & 4.89 & 5.23 & 5.44 & -0.08 & -0.58 & 0.80 \\
\hline Vitreous chamber depth & 13.99 & 14.42 & 15.01 & 15.58 & 16.25 & 16.90 & 18.31 & 2.90 & 12.41 & 1.24
\end{tabular}

AL: axial length; ACD: anterior chamber depth; LT: lens thickness; VCD: vitreous chamber depth.

The average $\mathrm{AL}$ in the Mexican population studied (23.44 $\mathrm{mm} \pm 1.71 \mathrm{~mm}$ ) was higher than that previously reported in an adult Chinese population (The Tanjong Pagar Survey: AL $23.23 \pm 1.17 \mathrm{~mm})^{8}$ and in an Indian adult population (The Central India Eye and Medical Study: AL $22.6 \pm 0.91 \mathrm{~mm})^{12,13}$. In an Iranian population, Hashemi et al. ${ }^{14}$ reported an average AL of $23.14 \mathrm{~mm}$. When analyzing the other factors, we also found lower 
average values with respect to the population studied. However, all these studies were conducted in Asian populations.

The Los Angeles Latino Eye Study ${ }^{15}$ included 5588 Latinos over 40 years of age, finding an average $A L$ value of $23.38 \pm 1.01 \mathrm{~mm}$, very similar to that of our population. These results support the assumption about ethnic importance in biometric values.

Villanueva-Pérez et al. (2009) ${ }^{16}$, in a comparative study in a Mexican population regarding ACD in 26 patients, found that the average ACD measured with immersion A-ultrasound biometry was of $3.29 \pm 0.37 \mathrm{~mm}$. We found that older people have a lower $\mathrm{AL}$, a narrower ACD, and a smaller VCD, but a higher LT. These biometric data coincide with measurement patterns observed in the previous studies in different populations $\mathbf{s}^{7,9}$. While an increase in AL is expected from childhood to adolescence, it is difficult to explain the shortening of the eye after middle age. One of the disadvantages of our study is the lack of comparison of these variations through time. However, Gudmundsdottir et al. ${ }^{17}$ demonstrated, in a 5-year cohort study, that this could be due to many unknown causes, including ocular atrophy.

A decrease in ACD and an increase in LT with age are another finding in this and other studies. The increase of LT with age is attributed to the regular apposition of crystalline fibers throughout life, which causes a decrease in $A C D^{18}$.

All the biometric data analyzed in this study were higher in men. All studies have shown higher $A L$ and $A C D$ values in men, but the results between $L T$ and gender have been conflicting.

\section{Conclusion}

$A L$ and its associated factors (ACD, LT, and VCD), compared to other studies conducted in Asian and American populations, showed average values. Except for LT, which increases with age, the rest of the values decreased with age. In addition, all biometric values were higher in men than in women.

\section{Conflicts of interest}

The authors declare no conflicts of interest.

\section{Ethical disclosures}

Protection of human and animal subjects. The authors declare that no experiments were performed on humans or animals for this study.

Confidentiality of data. The authors declare that they have followed the protocols of their work center on the publication of patient data.

Right to privacy and informed consent. The authors have obtained the written informed consent of the patients or subjects mentioned in the article. The corresponding author is in possession of this document.

\section{References}

1. Verhulst E, Vrijghem JC. Accuracy of intraocular lens power calculations using the Zeiss IOL master. A prospective study. Bull Soc Belge Ophtalmol. 2001:281:61-5.

2. Saka N, Ohno-Matsui K, Shimada N, Sueyoshi S, Nagaoka N, Hayashi W, et al. Long-term changes in axial length in adult eyes with pathologic myopia. Am J Ophthalmol. 2010;150:562-8.

3. Ruiz-Moreno JM, Montero JA, de la Vega C, Alio JL, Zapater P. Retinal detachment in myopic eyes after phakic intraocular lens implantation. J Refract Surg. 2006;22:247-52.

4. Hosny M, Alió JL, Claramonte P, Attia WH, Pérez-Santonja JJ. Relationship between anterior chamber depth, refractive state, corneal diameter and axial length. J Refractive Surgery. 2000;16(3):336-40.

5. Wang F, Zhou XD, Zhou SZ. Study of the relation between ocular axial biometry and refraction. Zhonghua Yan Ke Za Zhi. 1994;30(1):39-40.

6. Shih YF, Chiang TH, Lin LL. Lens thickness changes among schoolchildren in Taiwan. Invest Ophthalmol Vis Sci. 2009;50:2637-44.

7. Warrier S, Wu HM, Newland HS, Muecke J, Selva D, Aung T, et al. Ocular biometry and determinants of refractive error in rural Myanmar: the Meiktila Eye Study. Br J Ophthalmol. 2008;92:1591-4.

8. Wong TY, Foster PJ, Ng TP, Tielsch JM, Johnson GJ, Seah SK. Variations in ocular biometry in an adult Chinese population in Singapore: the Tanjong Pagar Survey. Invest Ophthalmol Vis Sci. 2001;42:73-80.

9. He M, Huang W, Li Y, Zheng Y, Yin Q, Foster PJ. Refractive error and biometry in older Chinese adults: the Liwan eye study. Invest Ophthalmol Vis Sci. 2009;50:5130-6.

10. Hoffer KJ. Axial dimension of the human cataractous lens. Arch Ophthalmol. 1993;111:914.

11. Hoffer KJ. Biometry of 7500 cataractous eyes. Am J Ophthalmol. 1981;99:360.

12. Jonas JB, Nangia V, Gupta R, Khare A, Sinha A, Agarwal S, et al. Anterior chamber depth and its associations with ocular and general parameters. The Central India Eye and Medical Study. Clin Experiment Ophthalmol. 2012;40:550-6.

13. Jonas JB, Nangia V, Gupta R, Sinha A, Bhate K. Lens thickness and associated factors. The Central India Eye and Medical Study. Clin Experiment Ophthalmol. 2012;40:583-90.

14. Hashemi H, Khabazhoob M, Miraftab M, Emamian MH, Shariati M, Abdolahinia $T$, et al. The distribution of axial length, anterior chamber depth, lens thickness, and vitreous chamber depth in an adult population of Shahroud, Iran. BMC Ophthalmol. 2012;12:50.

15. Shufelt C, Fraser-Bell S, Ying-Lai M, Torres M, Varma R. Los Angeles Latino Eye Study Group. Refractive error, ocular biometry, and lens opalescence in an adult population: The Los Angeles Latino Eye Study. Invest Ophthalmol Vis Sci. 2005;46:4450-60.

16. Villanueva G, Perdiz L. Profundidad de la cámara anterior mediante inmersión, Orbscanll, OCT Visante y UBM. Estudio comparativo. Rev Mex Oftalmol. 2009;83(4):221-5

17. Gudmundsdottir E, Arnarsson A, Jonasson F. Five-year refractive changes in an adult population: Reykjavik Eye Study. Ophthalmology. 2005:112:672-7.

18. Bron AJ, Vrensen GFJM, Koretz JF, Maraini G, Harding JJ. The ageing lens. Ophthalmologica. 2000;214:86-104. 